\title{
The Quality Characteristics of Commercial Gwamegi by Product Types
}

\author{
Hui-Seung Kang, Seung-Weon Jeong, Jong-Cheul Ko, Mi Jang, and Jong-Chan Kim \\ Korea Food Research Institute, Gyeonggi 463-746, Korea
}

\begin{abstract}
This study was performed to investigate the physical, chemical and microbial characteristics of Gwamegi to provide basic data for the standardization of marine processed foods and for the improvement of the quality of commercial Gwamegi. The acid values of commercial Gwamegi were 5.8, 5.3 and $5.2 \mathrm{mg} \mathrm{KOH} / \mathrm{g}$ for fillet type (F-type), "two divide" type (T-type) and whole type (W-type), respectively, and the peroxide values were 51.6, 51.5 and $53.2 \mathrm{meq} / \mathrm{kg}$ for each. There was a positive correlation between the acid value and the peroxide value $(\mathrm{r}=\mathbf{0 . 5 5 5})$ at confidence intervals (CI) of $99 \%$ Trimethylamine (TMA) content of F-type, T-type and W-type products were 2.9, 2.6 and $3.6 \mathrm{mg} \%$, respectively, while volatile basic nitrogen (VBN) contents were 22.4, 21.5 and $21.8 \mathrm{mg} \%$. There was a strong positive comelation between TMA and VBN (r=0.961) at a CI of 99\%. The histamine content was detected to be as much as $122 \mathrm{mg} / \mathrm{kg}$, with about $36 \%$ of the samples exceeding the CODEX criteria for histamine of $100 \mathrm{mg} / \mathrm{kg}$. The total microbial count of 4 products exceeded $5 \mathrm{Log} \mathrm{CFU} / \mathrm{g}$ and coliform group of 11 products exceeded the criteria of less than $1 \mathrm{Log}$ CFU/g. Staphylococcus aureus in $27 \%$ of the samples exceeded the criteria of less than $2 \mathrm{Log} \mathrm{CFU} / \mathrm{g}$.
\end{abstract}

Key words: Gwamegi, pacific saury, quality characteristics, histamine, microbial characteristics

\section{INTRODUCTION}

Gwamegi is a semi-dried marine processed product that is traditionally made by naturally drying blue-back fish, such as saury and herring, for more than 15 days during wintertime until the moisture content reaches about $30 \%$ (1). Gwamegi production sites are generally located in the east coastal area of Korea, including Pohang City, with the drying process taking place in the shade using sea winds. Gwamegi has superior nutritional value and unique flavor, and its consumption is steadily increasing. It has recently been reported that the demand for Gwamegi is not limited to the Pohang area, but has expanded nationwide, and that many factories now manufacture it using mechanical methods, such as a cold wind drier. (2) In the past, Gwamegi was produced using herring as the main material. However, since the 1960s, when the catch of herring rapidly decreased and the drying conditions changed due to rising temperatures, saury became the main material for Gwamegi (3).

While the product is being dried, the tissues of Gwamegi mature to produce a unique flavor with a high level of unsaturated fatty acids. Indeed, the product has been shown to be effective in preventing adult diseases like arteriosclerosis and hypertension (4). In particular, Gwamegi contains a lot of eicosapentaenoic acid (EPA) and docosahexaenoic acid (DHA), which are effective in ex- panding blood vessels, restraining the cohesion of a blood platelet, and lowering blood pressure (5). Recent research into Gwamegi includes investigating changes in ingredients according to the conditions for manufacturing Gwamegi $(6,7)$, an investigation into physio-chemical and hygienic quality characteristics according to storage conditions $(8,9)$, comparing the ingredients while various functional materials are added $(4,10)$, and research on nutritional ingredients and biogenic amine content of commercial Gwamegi $(2,11)$.

The natural drying method, in which Gwamegi is dried until its moisture content reaches about $30 \%$, may deteriorate the quality of the product because it not only accelerates the multiplication of pathogenic microorganism inflow during manufacturing processes, but also facilitates the growth of microorganisms during rainy or hot days (12). Moreover, many food safety problems may arise since biogenic amine is excessively generated due to poor processing and distribution conditions. In this regard, a relevant food hygienic criteria needs to be considered to improve the manufacturing processes and control the quality of Gwamegi; to do that, research must be conducted into the hygienic and quality characteristics of Gwamegi on the market. Therefore, this research aims to analyze physical, chemical and microbiological characteristics of commercial Gwamegi, with a view to providing basic data for quality control of the product and 
for the standardization of marine processed foods and contributing to the improvement of the quality of commercial Gwamegi.

\section{MATERIALS AND METHODS}

In February 2010, 22 kinds of commercial Gwamegi were purchased from large stores in Seongnam city, Korea and online markets: 20 of which were made from saury and 2 of which were made from herring, which were imported from the North Pacific, where they were caught, frozen, processed and stored at less than $-18^{\circ} \mathrm{C}$. Table 1 shows each sample's treatment, packaging conditions, added ingredients, and fish species.

The twenty-two samples were classified according to their treatment conditions: four are a fillet type (F-type), which is cut into the size of a bite after the non-edible portions are completely removed, fourteen are a two divide type (T-type), in which the fish is cut into two pieces, the intestines are removed but the skin is not, four kinds are a whole type (W-type) which is dried with the non-edible portions not removed. Additionally, six kinds have some added ingredients (Japanese apricot, green tea, lemon, chitosan and medicinal herbs) to improve the quality, and sixteen of the samples are common Gwamegi.

\section{Proximate composition}

According to the AOAC (13) method, moisture was analyzed at $105^{\circ} \mathrm{C}$ by using air oven drying method, the crude protein content by Kjeldahl nitrogen determination method, and the crude fat content by Soxhlet method.

\section{Acid value}

According to Folch et al. (14), lipid was extracted in chloroform-methanol $(2: 1, \mathrm{v} / \mathrm{v})$ solution whose quantity was 10 times as much as that of the samples; and then, according to AOCS methodology (15), the acid value was measured. Five grams of oil and fat samples were weighed and $100 \mathrm{~mL}$ of neutral ether-ethanol mixed solution was added to completely dissolve the sample. The phenolphthalein was used as an indicator and the acid value was measured by titrating with $0.1 \mathrm{~N} \mathrm{KOH}-$ alcohol.

\section{Peroxide value}

The peroxide value was measured according to AOAC (13). In the same way as in the case of the acid value, $1 \mathrm{~g}$ of extracted oil and fat sample was precisely weighed and put into a flask. Ten $\mathrm{mL}$ of chloroform was added to the sample and dissolved and then $15 \mathrm{~mL}$ of nitric acid was added. Also, $1 \mathrm{~mL}$ of $\mathrm{KI}$ saturated solution was added, sufficiently shaken with the stopper closed for 1 minute and then left in a dark place for ten minutes. After that, $30 \mathrm{~mL}$ of distilled water was added, sufficiently shaken with the stopper closed, and then 0.01 $\mathrm{N} \mathrm{Na} \mathrm{S}_{2} \mathrm{O}_{3}$ solution dripped into the mixture while 1 $\%$ starch solution was added as an indicator until the

Table 1. Summary of product types, packaging conditions, treated ingredients and fish species of commercial Gwamegi used in the experiment

\begin{tabular}{|c|c|c|c|c|}
\hline Product types & Sample code & Fish species & Packaging conditions & Treated ingredients \\
\hline \multirow{4}{*}{ Fillet type } & 1 & Pacific saury & Aerobic & $\mathrm{NT}^{1)}$ \\
\hline & 2 & Pacific saury & Aerobic & Japanese apricot \\
\hline & 3 & Pacific saury & Vacuum & Green tea, lemon \\
\hline & 4 & Pacific saury & Vacuum & Green tea \\
\hline \multirow{14}{*}{ Two divide type } & 5 & Pacific saury & Aerobic & NT \\
\hline & 6 & Pacific saury & Aerobic & NT \\
\hline & 7 & Pacific saury & Aerobic & NT \\
\hline & 8 & Pacific saury & Aerobic & NT \\
\hline & 9 & Pacific saury & Aerobic & NT \\
\hline & 10 & Pacific saury & Aerobic & Green tea \\
\hline & 11 & Pacific saury & Aerobic & NT \\
\hline & 12 & Pacific saury & Aerobic & NT \\
\hline & 13 & Pacific saury & Aerobic & Chitosan \\
\hline & 14 & Pacific saury & Aerobic & Medical herb \\
\hline & 15 & Pacific saury & Vacuum & NT \\
\hline & 16 & Pacific saury & Vacuum & NT \\
\hline & 17 & Pacific saury & Vacuum & NT \\
\hline & 18 & Pacific herring & Aerobic & NT \\
\hline \multirow{4}{*}{ Whole type } & 19 & Pacific saury & Aerobic & NT \\
\hline & 20 & Pacific saury & Aerobic & NT \\
\hline & 21 & Pacific saury & Aerobic & NT \\
\hline & 22 & Pacific herring & Aerobic & NT \\
\hline
\end{tabular}

${ }^{1)}$ Not treated. 
bluish navy color turned completely colorless.

\section{Volatile basic nitrogen (VBN)}

VBN was measured using Conway micro-diffusion method (16). In other words, $2 \mathrm{~g}$ of sample was added to $16 \mathrm{~mL}$ of distilled water and $2 \mathrm{~mL}$ of $20 \%$ trichloroacetic acid, stirred for 2 minutes using a blender, and then filtrated and prepared. The remaining $1 \mathrm{~mL}$ of sample was put into the outer chamber of a Conway dish, $1 \mathrm{~mL}$ of $0.01 \mathrm{~N} \mathrm{H}_{3} \mathrm{BO}_{3}$ into the inner chamber, and 1 $\mathrm{mL}$ of saturated $\mathrm{K}_{2} \mathrm{CO}_{3}$ was quickly poured into the outer chamber, which was to be tightly sealed. Then, the sample was shaken so that test solutions might be mixed in the outer chamber and left at $37^{\circ} \mathrm{C}$ for 80 minutes. After the reaction, $0.02 \mathrm{~N} \mathrm{HCl}$ solution was dripped into the dish to take a measurement.

\section{Trimethylamine (TMA)}

TMA was determined using Conway micro-diffusion method (17). As with VBN measurement, the remaining $1 \mathrm{~mL}$ of the prepared sample was put into the outer chamber and $1 \mathrm{~mL}$ of $0.01 \mathrm{~N} \mathrm{H}_{3} \mathrm{BO}_{3}$ into the inner chamber. Again, the outer chamber was filled with $1 \mathrm{~mL}$ of saturated $\mathrm{K}_{2} \mathrm{CO}_{3}$ and $1 \mathrm{~mL}$ of neutral formalin solution and then tightly closed. After that, the sample was shaken so that test solutions might be mixed in the outer chamber and left at $37^{\circ} \mathrm{C}$ for 120 minutes for reaction. After the reaction, $0.02 \mathrm{~N} \mathrm{HCl}$ solution was dripped into the dish to take a measurement.

\section{Histamine}

According to AOAC (13), $10 \mathrm{~g}$ of sample was added with $50 \mathrm{~mL}$ of $75 \%$ methanol, homogenized for $2 \mathrm{mi}-$ nutes, heated and dissolved in $60^{\circ} \mathrm{C}$ water bath for about 15 minutes, then filtrated through filter paper. Again, 50 $\mathrm{mL}$ of $75 \%$ methanol was added to the residue on the filter paper, the same procedure as VBN was followed, and the residue was quantified to $100 \mathrm{~mL}$ to be used as a test sample. One $\mathrm{mL}$ of the produced sample was taken, ion exchange resin (Bio-Rad, Hercules, CA, USA) was added with $4 \sim 5 \mathrm{~mL}$ of distilled water, $35 \mathrm{~mL}$ of eluate was put into a volumetric flask containing $5 \mathrm{~mL}$ of $1 \mathrm{M} \mathrm{HCl}$, and then the sample was quantitied to 50 $\mathrm{mL}$ by using distilled water. Five $\mathrm{mL}$ each of the test solution and the standard solution was mixed with 10 $\mathrm{mL}$ of $0.1 \mathrm{M} \mathrm{HCl}$, combined with $3 \mathrm{~mL}$ of $1 \mathrm{M} \mathrm{NaOH}$, and then, within 5 minutes, mixed with $1 \mathrm{~mL}$ of OPT solution. Again, $3 \mathrm{~mL}$ of $\mathrm{H}_{2} \mathrm{PO}_{4}$ was added and mixed in exactly 4 minutes and, within 90 minutes, the absorbance in excitation spectrum (Em: $350 \mathrm{~nm}$ ) and emission spectrum (Ex: $444 \mathrm{~nm}$ ) was measured by using a spectrophotometer (SpectraMax M2, MDS Analytical Technologies, Sunnyvale, CA, USA) so as to determine the content of histamine in the sample.

\section{Total microbial count}

To know the total microbial count, $25 \mathrm{~g}$ of sample was added with $225 \mathrm{~mL}$ of sterilized diluted solution $(0.85 \%$ $\mathrm{NaCl}$, w/v), homogenized by using a stomacher (400 circulator, Seward, London, UK), 10 times serially diluted, distributed with plate count agar (Difco, Sparks, MD, USA), and cultured in a $35 \pm 1{ }^{\circ} \mathrm{C}$ incubator (HB-103M, Hanbaeck, Bucheon, Korea) for 48 hours to determine the number of colonies.

\section{Coliform group}

Similar to the method used to determine the total microbial count, coliform group was measured through inoculating $1 \mathrm{~mL}$ of test undiluted solution to a plate, where the sample was cultured by using a deoxycholate lactose agar (Difco) medium at $37^{\circ} \mathrm{C}$ for 48 hours, so as to determine formed colonies.

\section{E. coli}

To count E. coli, EC broth (Oxoid, Hampshire, UK) was inoculated with $1 \mathrm{~mL}$ of each sample, cultured and enriched at $37^{\circ} \mathrm{C}$ for 24 hours. After using a Durham tube to confirm that gas was emitted, the sample was taken by a loop, smeared onto EMB agar (Difco), cultivated at $37^{\circ} \mathrm{C}$ for 24 hours and then counted. Colonies whose shape appeared to be $E$. coli were selected, purely cultured or molded in tryptic soy agar (Difco) and identified by using API 20E kit (Biomerieux, Marcy l'Etoile, France).

\section{S. aureus}

Twenty-five $\mathrm{g}$ of sample was added to tryptic soy broth (Difco) including $225 \mathrm{~mL}$ of $10 \% \mathrm{NaCl}$ and enriched and cultured at $35 \sim 37^{\circ} \mathrm{C}$ for 16 hours. Then, the sample was moved to Baird-Parker agar (Difco) selective medium, where it was cultivated at $37^{\circ} \mathrm{C}$ for $24 \sim 48$ hours, and its positive colonies were identified by using API 20E kit (Biomerieux). Moreover, $25 \mathrm{~g}$ of the sample was added to $225 \mathrm{~mL}$ of sterilized diluted solution, and this test solution was diluted 10 times and smeared on a Baird-Parker agar (Difco) selective medium and then cultivated at $37^{\circ} \mathrm{C}$ for 48 hours. In the same way as the above identification test, positive colonies in which Staphylococcus aureus was identified were counted.

\section{Statistical analysis}

The statistical significance between samples was determined by employing Duncan's multiple range test after analysis of variance (one-way ANOVA) was conducted using SPSS software package (version 18.0) according to their treatment type; and the significance of the treatment group and the control group of added in- 
Table 2. Proximate composition of commercial Gwamegi by product types

\begin{tabular}{cccccc}
\hline \multirow{2}{*}{ Product types $^{1)}$} & \multirow{2}{*}{ Number of samples } & \multicolumn{5}{c}{ Proximate composition (\%) } \\
\cline { 3 - 6 } & & Moisture & Protein & Lipid & Ash \\
\hline F-type & 4 & $37.4 \pm 3.8^{\mathrm{ab} 3)}$ & $31.6 \pm 0.9^{\mathrm{NS} 4)}$ & $27.7 \pm 3.5^{\mathrm{NS}}$ & $2.3 \pm 0.6^{\mathrm{NS}}$ \\
T-type & 14 & $33.9 \pm 5.3^{\mathrm{a}}$ & $32.0 \pm 4.4$ & $29.4 \pm 4.0$ & $2.4 \pm 0.6$ \\
W-type & 4 & $42.6 \pm 6.1^{\mathrm{b}}$ & $30.4 \pm 2.0$ & $24.4 \pm 4.1$ & $1.8 \pm 0.2$ \\
\hline \multicolumn{2}{c}{ Total average } & $36.1 \pm 5.9$ & $31.7 \pm 3.6$ & $28.2 \pm 4.2$ & $2.3 \pm 0.5$ \\
\hline
\end{tabular}

${ }^{1)}$ F-type, fillet type; T-type, two divide type; W-type, whole type.

${ }^{2)}$ All values are mean $\pm \mathrm{SD}$ of triplicate determinations.

${ }^{3)}$ Different superscript letters in the same column show significant differences at $\mathrm{p}<0.05$ by one-way ANOVA and Duncan's multiple range test.

${ }^{4)}$ Not significant.

gredients was determined through $t$-test. Furthermore, the correlation between such interactive variables as physical and chemical measurements was analyzed and all the statistical significances were identified at the level of $\mathrm{p}<0.05$.

\section{RESULTS AND DISCUSSION}

\section{Proximate composition}

Table 2 shows the results of the analysis of 22 types of commercial Gwamegi, which are classified according to their treatment conditions. The moisture contents of commercial Gwamegi were $36.1 \sim 42.3 \%$ for F-type, $26.4 \sim 41.4 \%$ for T-type and $34.7 \sim 47.9 \%$ for W-type, indicating that $\mathrm{W}$-type has a significantly higher moisture content than T-type $(\mathrm{p}<0.05)$. Such a result is believed to be due to the fact that each type has a different drying efficiency during its manufacturing process. The crude protein content was $30.4 \sim 32.4 \%$ for F-type, 25.7 $\sim 41.6 \%$ for T-type and $29.3 \sim 33.5 \%$ for W-type. The crude fat content was $23.6 \sim 31.2 \%$ for F-type, $20.7 \sim$ $36.7 \%$ for T-type and $20.0 \sim 28.8 \%$ for W-type. The ash content was $1.7 \sim 3.0 \%$ for F-type, $1.7 \sim 3.5 \%$ for T-type and $1.6 \sim 2.1 \%$ for $\mathrm{W}$-type. There was no significant difference among the crude protein content, the crude fat content and the ash content depending upon the treatment type $(p>0.05)$. Lee et al. (8) reported that there was no difference between the crude protein content and the crude fat content of Gwamegi of different treatment types and Yoon et al. (11) reported that there was no difference in the ash content of different commercial Gwamegi samples, which is a similar result to this research.

\section{Acid value and peroxide value}

Acid and peroxide values show the degree of acidification of oils and fats and are often used as indices of the quality of foods containing oils and fats (9). In general, Gwamegi contains lots of lipids and has a high level of polyunsaturated fatty acids. During its drying and distributing processes, lipid oxidizes easily, so regulations on the acidification of lipids must be established. The acid value of the commercial Gwamegi samples was measured and found to be 5.8, 5.3 and $5.2 \mathrm{mg} \mathrm{KOH} / \mathrm{g}$ for F-type, T-type and W-type, respectively and that there was no significant difference among the treatment types (Table 3). Food Code (KFDA, 2010) stipulates that the acid value of fried or oil-treated foods should be less than $5.0 \mathrm{mg} \mathrm{KOH} / \mathrm{g}$. Sixty-three percent of commercial Gwamegi exceed the scope of this stipulation, which urgently suggests the need for research into how to diminish the acidification of Gwamegi. The peroxide value was $51.6,51.5$ and $53.2 \mathrm{meq} / \mathrm{kg}$ for F-type, T-type and $\mathrm{W}$-type, respectively; there was no significant difference among the treatment types, considering the large deviation (Table 3). Oh and Kim (18) reported that the peroxide value of Gwamegi would increase to $33 \mathrm{meq} / \mathrm{kg}$ though natural drying, and Yoon et al. (11) reported that the peroxide value of frozen and refrigerated Gwamegi was 45.9 and $49.8 \mathrm{meq} / \mathrm{kg}$, respectively. In comparison, the

Table 3. Acid value and peroxide value of commercial Gwamegi by product types

\begin{tabular}{ccccccc}
\hline \multirow{2}{*}{ Product types ${ }^{1)}$} & \multirow{2}{*}{ Number of samples } & \multicolumn{2}{c}{ Acid value $(\mathrm{mg} \mathrm{KOH} / \mathrm{g})$} & & \multicolumn{2}{c}{ Peroxide value $(\mathrm{meq} / \mathrm{kg})$} \\
\cline { 3 - 4 } \cline { 6 - 7 } F-type & 4 & Average $^{2)}$ & Range & & Average & Range \\
T-type & 14 & $5.8 \pm 3.9^{\mathrm{NS} 3)}$ & $1.7 \sim 10.3$ & & $51.6 \pm 22.8^{\mathrm{NS}}$ & $24.6 \sim 80.0$ \\
W-type & 4 & $5.3 \pm 2.1$ & $1.1 \sim 7.3$ & & $51.5 \pm 23.0$ & $17.5 \sim 80.1$ \\
\hline \multicolumn{2}{c}{ Total average } & $5.2 \pm 1.1$ & $3.8 \sim 6.1$ & & $53.2 \pm 6.0$ & $48.8 \sim 61.8$ \\
\hline
\end{tabular}

\footnotetext{
${ }^{1)}$ Products types as in Table 2.

${ }^{2)}$ All values are mean $\pm \mathrm{SD}$ of triplicate determinations.

${ }^{3)}$ Not significant.
} 

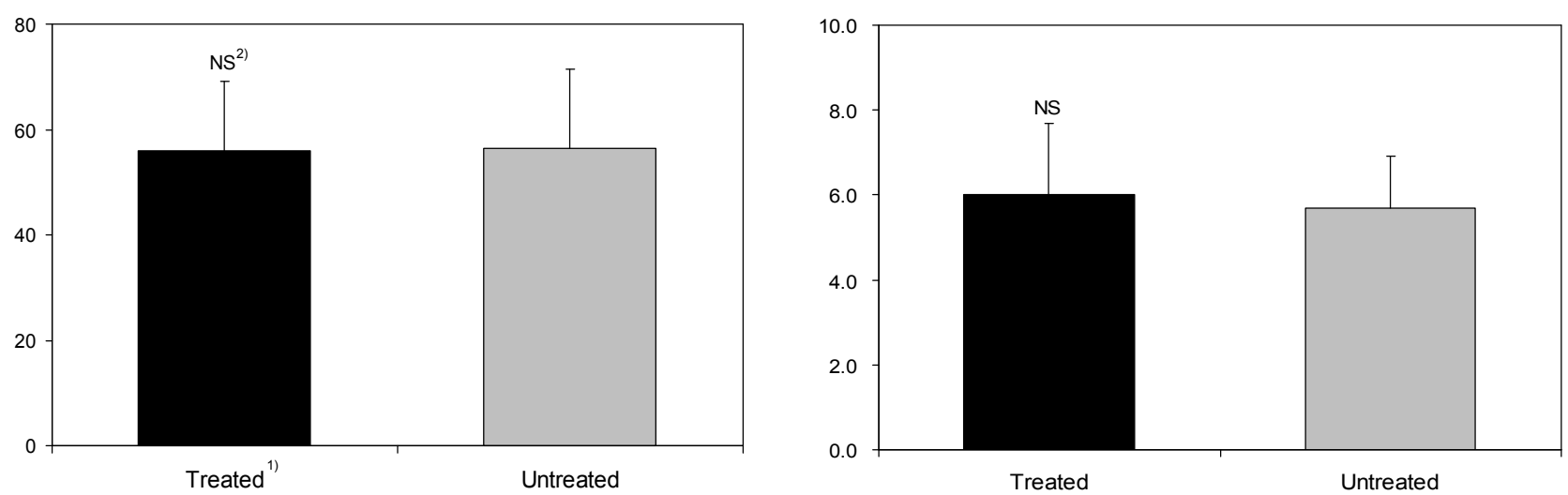

Fig. 1. Acid value and peroxide value on commercial Gwamegi by treated ingredients. ${ }^{1)}$ Treated ingredients (Japanese apricot, green tea, lemon, chitosan, herb) on Gwamegi. ${ }^{2)}$ Not significant.

results of this research are somewhat higher.

Recently, research into how to add functional materials and how to package the Gwamegi to decrease acidification are being conducted. Fig. 1 shows the results of comparing and analyzing the acid values and the peroxide values of commercial Gwamegi containing added ingredients (Japanese apricot, green tea, lemon, chitosan and medicinal herbs) and common Gwamegi (untreated). It was found that the acid values and the peroxide values of treated Gwamegi and common Gwamegi were 6.0 and $5.7 \mathrm{mg} \mathrm{KOH} / \mathrm{g}$ and 55.9 and $56.4 \mathrm{meq} / \mathrm{kg}$ with no significant difference in the respective values. This implies that it is difficult to restrain the acidification of lipids taking place during manufacturing processes, even with coating the fish with extra ingredients. Therefore, supplementary research needs to be performed to determine methods that minimize automatic oxidation and acidification of lipids generated during the creation of Gwamegi.

Trimethylamine (TMA) and volatile basic nitrogen (VBN)

TMA and VBN are generated while fresh fish or meat is decomposed by microorganisms. These values are an indirect index to measure the freshness of foods and may be used as a criterion for evaluating the corruption of fish in storage (19). VBN includes volatile basic nitrogen compounds such as TMA, various basic amines, and am- monia (20). The TMA and VBN contents of commercial Gwamegi were measured and the TMA levels were 2.9, 2.6 and $3.6 \mathrm{mg} \%$ for F-type, T-type and W-type, respectively, with no significant difference among the treatment types. VBN contents were 22.4, 21.5 and 21.8 $\mathrm{mg} \%$ for F-type, T-type and W-type, respectively, with no significant difference among the treatment types (Table 4). Yoon et al. (7) report that the volatile basic nitrogen content of refrigerated and frozen Gwamegi was $21.7 \sim 30.0$ and $22.2 \sim 30.2 \mathrm{mg} \%$, which is similar to the results of this research. Lee et al. (21) report that the VBN content of fish was low immediately after a catch, but increased as the freshness deteriorated. This suggests that the VBN content increased during the drying process of commercial Gwamegi.

\section{Histamine}

Since Gwamegi is manufactured through long-time natural drying, the meat corrupts at an early stage, when histamine is generated due to the de-carbonizing action of histidine contained in fish. Histamine does not easily decompose and is known to be a cause for allergic food poisoning (12). Measurement of the histamine content in commercial Gwamegi indicated that there is a large deviation among the products, ranging from 22.4 to 122 $\mathrm{mg} / \mathrm{kg}$ (Table 5). Food Code only stipulates the maximum level of histamine for tuna fish, which is less than $200 \mathrm{mg} / \mathrm{kg}$ while CODEX standards stipulate that the

Table 4. TMA and VBN of commercial Gwamegi by product types

\begin{tabular}{|c|c|c|c|c|c|}
\hline \multirow{2}{*}{ Product types ${ }^{1)}$} & \multirow{2}{*}{ Number of samples } & \multicolumn{2}{|c|}{ TMA (mg\%) } & \multicolumn{2}{|c|}{ VBN $\left(\mathrm{mg}^{2} \%\right)$} \\
\hline & & Average $^{2)}$ & Range & Average & Range \\
\hline F-type & 4 & $2.9 \pm 0.8^{\mathrm{NS} 3)}$ & $1.7 \sim 3.6$ & $22.4 \pm 5.5^{\mathrm{NS}}$ & $15.5 \sim 29.0$ \\
\hline T-type & 14 & $2.6 \pm 1.5$ & $1.1 \sim 6.2$ & $21.5 \pm 5.0$ & $12.8 \sim 31.5$ \\
\hline W-type & 4 & $3.6 \pm 2.4$ & $0.9 \sim 5.4$ & $21.8 \pm 6.8$ & $16.4 \sim 29.5$ \\
\hline \multicolumn{2}{|c|}{ Total average } & \multicolumn{2}{|c|}{$2.8 \pm 1.5$} & \multicolumn{2}{|c|}{$21.7 \pm 5.1$} \\
\hline
\end{tabular}

\footnotetext{
${ }^{1)}$ Products types as in Table 2.

${ }^{2)}$ All values are mean $\pm \mathrm{SD}$ of triplicate determinations.

${ }^{3)}$ Not significant.
} 
Table 5. Histamine content of commercial Gwamegi by product types

\begin{tabular}{cccc}
\hline \multirow{2}{*}{$\begin{array}{c}\text { Product } \\
\text { types }\end{array}$} & \multirow{2}{*}{$\begin{array}{c}\text { Number of } \\
\text { samples }\end{array}$} & \multicolumn{2}{c}{ Histamine $(\mathrm{mg} / \mathrm{kg})$} \\
\cline { 3 - 4 } & & Average $^{2)}$ & Range \\
\hline F-type & 4 & $\left.61.7 \pm 46.8^{\mathrm{NS} 3}\right)$ & $30.8 \sim 115.5$ \\
T-type & 14 & $80.6 \pm 32.4$ & $30.9 \sim 122.3$ \\
W-type & 4 & $59.6 \pm 27.3$ & $22.4 \sim 86.1$ \\
\hline \multicolumn{2}{c}{ Total average } & \multicolumn{2}{c}{$77.8 \pm 33.3$} \\
\hline
\end{tabular}

${ }^{1)}$ Product types as in Table 2.

${ }^{2)}$ All values are mean $\pm \mathrm{SD}$ of triplicate determinations.

${ }^{3)}$ Not significant.

level should be less than $100 \mathrm{mg} / \mathrm{kg}$.

It was found that no products went beyond the scope stipulated in Food Code, i.e., $200 \mathrm{mg} / \mathrm{kg}$, but about 36 $\%$ of the products violated the CODEX stipulation or $100 \mathrm{mg} / \mathrm{kg}$. The CODEX international stipulation should be observed so that Gwamegi may freely advance into overseas markets.

\section{Total microbial count}

Table 6 shows the total microbial count of 22 kinds of Gwamegi. It was found that a product of F-type and three products of T-type went beyond the scope of the total microbial count of Gwamegi, which is 5 Log CFU/ $\mathrm{g}$, as suggested in the quality criteria for each item of marine products and marine indigenous products as proposed by National Fisheries Products Quality Inspection
Service (NFIS) in Korea. Among the 6 samples of commercial Gwamegi containing the added ingredients of Japanese apricot, green tea, lemon, chitosan or medicinal herbs; four products exceeded the scope of the total microbial count suggested in the quality criteria for each item of marine products and marine indigenous products by NFIS, which indicates that the added ingredients did not affect the total microbial count of commercial Gwamegi.

\section{Coliform group and $E$. coli}

Coliform group and E. coli levels in the 22 commercial Gwamegi samples were measured, and coliform group was detected from 11 items and E. coli from 1 item (Table 4). The quality criteria for each item of marine products and marine indigenous products by NFIS stipulates that coliform group should be less than $1 \mathrm{Log}$ $\mathrm{CFU} / \mathrm{g}$. Eleven samples of commercial Gwamegi violated that criteria: two of which were F-type, eight were T-type and one was W-type. Since Gwamegi has a high level of moisture content and a long drying time, it may be easily contaminated by microorganisms. Thus, further research should be done into Gwamegi manufacturing processes to determine methods to prevent microbiologic contamination (22).

\section{S. aureus}

Staphylococcus aureus was detected in ten of the com-

Table 6. Total microbial count and coliform group of commercial Gwamegi by product types

\begin{tabular}{|c|c|c|c|c|c|c|}
\hline \multirow{2}{*}{$\begin{array}{l}\text { Product } \\
\text { types } 1)\end{array}$} & \multirow{2}{*}{$\begin{array}{c}\text { Sample } \\
\text { code }\end{array}$} & \multirow{2}{*}{ Added ingredients } & \multicolumn{4}{|c|}{ Microbial count $(\mathrm{CFU} / \mathrm{g})^{2)}$} \\
\hline & & & Total microbial count & Coliform group & E. coli & S. aureus \\
\hline \multirow{4}{*}{ F-type } & 1 & - & $2.1 \times 10^{3}$ & $2.0 \times 10^{2}$ & ND & $9.6 \times 10^{2}$ \\
\hline & 2 & Japanese apricot & $\mathrm{ND}^{3)}$ & ND & ND & ND \\
\hline & 3 & Green tea, lemon & $2.1 \times 10^{3}$ & ND & ND & ND \\
\hline & 4 & Green tea & $4.8 \times 10^{5}$ & $1.8 \times 10^{5}$ & ND & ND \\
\hline \multirow{14}{*}{ T-type } & 5 & - & $9.8 \times 10^{3}$ & $1.0 \times 10^{1}$ & ND & $5.2 \times 10^{3}$ \\
\hline & 6 & - & $2.7 \times 10^{4}$ & $3.8 \times 10^{2}$ & ND & $2.0 \times 10^{2}$ \\
\hline & 7 & - & $1.5 \times 10^{5}$ & $1.4 \times 10^{3}$ & ND & $1.3 \times 10^{4}$ \\
\hline & 8 & - & $7.3 \times 10^{4}$ & $5.8 \times 10^{2}$ & ND & ND \\
\hline & 9 & - & $1.2 \times 10^{2}$ & ND & ND & ND \\
\hline & 10 & Green tea & $1.2 \times 10^{3}$ & $1.4 \times 10^{2}$ & ND & $6.2 \times 10^{2}$ \\
\hline & 11 & - & $8.7 \times 10^{3}$ & ND & ND & $9.3 \times 10^{2}$ \\
\hline & 12 & - & $2.1 \times 10^{4}$ & $\mathrm{ND}$ & ND & ND \\
\hline & 13 & Chitosan & $2.2 \times 10^{5}$ & $1.2 \times 10^{4}$ & ND & $3.7 \times 10^{1}$ \\
\hline & 14 & Herb & $1.3 \times 10^{5}$ & $2.5 \times 10^{4}$ & ND & $6.0 \times 10^{2}$ \\
\hline & 15 & - & $7.5 \times 10^{2}$ & ND & ND & $9.0 \times 10^{1}$ \\
\hline & 16 & - & $2.3 \times 10^{2}$ & ND & ND & ND \\
\hline & 17 & - & $7.6 \times 10^{3}$ & $7.5 \times 10^{2}$ & $3.0 \times 10^{1}$ & $4.1 \times 10^{2}$ \\
\hline & 18 & - & ND & ND & ND & ND \\
\hline \multirow{4}{*}{ W-type } & 19 & - & $1.2 \times 10^{2}$ & ND & ND & ND \\
\hline & 20 & - & ND & $\mathrm{ND}$ & ND & ND \\
\hline & 21 & - & $5.1 \times 10^{3}$ & ND & ND & ND \\
\hline & 22 & - & $9.1 \times 10^{3}$ & $2.6 \times 10^{3}$ & ND & ND \\
\hline
\end{tabular}

${ }^{1)}$ Product types as in Table 2.

${ }^{2)}$ All values are expressed in the mean of duplicate determinations

${ }^{3)}$ Not detected. 
Table 7. Correlation coefficients of the commercial Gwamegi among the analytical variables

\begin{tabular}{lccccrrr}
\hline Variables & Moisture & Crude protein & Crude fat & Acid value & Peroxide value & TMA & VBN \\
\hline Histamine & 0.116 & 0.119 & $-0.228^{* *}$ & $0.588^{*}$ & -0.078 & -0.039 & 0.103 \\
Moisture & & -0.378 & $-0.794^{* *}$ & 0.094 & 0.161 & 0.405 & 0.350 \\
Crude protein & & & -0.173 & 0.257 & -0.293 & -0.186 & -0.152 \\
Crude fat & & & & -0.100 & $0.111^{* *}$ & -0.338 & -0.290 \\
Acid value & & & & & $0.555^{* *}$ & -0.097 & -0.004 \\
Peroxide value & & & & & & 0.134 & 0.175 \\
TMA & & & & & & $0.961^{* *}$ \\
\hline
\end{tabular}

Level of significance: ${ }^{*} \mathrm{p}<0.05,{ }^{* *} \mathrm{p}<0.01$.

mercial Gwamegi samples (Table 4). Nine of the samples testing positive were T-type and one was F-type. Food Code stipulates that less than $2 \mathrm{Log} \mathrm{CFU} / \mathrm{g}$ of $S$. aureus should be detected from vulnerable products, and it was found that about $27 \%$ of our Gwamegi samples violated that stipulation. S. aureus is a pathogenic microorganism that generates enterotoxins, which can cause food poisoning. This research found that the level of $S$. aureus contamination of commercial Gwamegi was less than 6 Log CFU/g, an amount at which enterotoxin may be generated, according to a report released by Walls and Scatt (23).

\section{Correlation coefficients}

Table 7 shows the results of a correlation analysis between the general ingredients of commercial Gwamegi and its chemical characteristics, with the goal of creating quality indices for the product. As for general ingredients, at the confidence $(\mathrm{CI})$ of $99 \%$, there was a strong negative correlation between the moisture content and the crude fat content $(\mathrm{r}=-0.794)$. Oh et al. (3) reported that the weight of crude fat increased relatively more than its proportionate weight at the early stage of drying as the moisture content decreased during the drying process. There was a positive correlation with a CI of $99 \%$ between the acid value and the peroxide value, which are indices of the acidification $(\mathrm{r}=0.555)$. A report on the acidification of oil and fat depending upon the storage period after the manufacture of Gwamegi reveals that the acid value rapidly increased in the first two months, then slowly increased after that, but the peroxide value quickly increased after two months (9). It seems that an increase of peroxides can be restrained by controlling the acidification which occurred in Gwamegi at the early stage. Therefore, additional study needs to be conducted into the suppression of acidification. With the positive correlation between the acid value and the histamine content (CI of 95\%; $\mathrm{r}=0.588$ ), it appears that there needs to be additional research into effects of the acid value on the generation of histamine. At a CI of $99 \%$, there was a strong positive correlation between TMA and VBN ( $\mathrm{r}=0.961)$, which indicates the freshness of fish.
Our study implies that one of these indices (VBN and TMA) may be controlled and used as a freshness index for Gwamegi.

\section{REFERENCES}

1. Jang MS, Park HY, Byun HS, Park JI, Kim YK, Yonn NY, Nam CS. 2010. The nutrient composition of commercial kwamegi admixed with functional ingredients. Korean J Food Preserv 17: 519-525.

2. Yoon MS, Heu MS, Kim JS. 2010. Fatty acid composition, total amino acid and mineral contents of commercial $k w a-$ megi. Kor J Fish Aquat Sci 43: 100-108.

3. Oh SH, Kim DJ, Choi KH. 1998. Changes in compositions of pacific saury (Cololabis seira) flesh during drying for production of kwamaegi. J Korean Soc Food Sci Nutr 27: 386-392.

4. Cho SH, Kwon EH, Oh SH, Woo MH. 2009. Suppressive effects of the extract of Zanthoxylum schinifolium and essential oil from Zanthoxylum piperitum on pacific saury, Coloabis saira Kwamegi. J Korean Soc Food Sci Nutr 38: 1753-1759.

5. Kim DK, Kim JW, Oh SH, Lee SI, Kim MJ, Kim SD. 2009. The effect of chitosan-ascorbate treated kwamaegi on serum lipid profiles and ROS-related enzyme activities in rats. J East Asian Soc Dietary Life 19: 987-995.

6. Lee HJ. 2005. Effect of storage materials, types, temperatures, and durations on the component changes of pacific saury, Cololabis saira kwamaegi. PhD Dissertation. University of Daegu, Daegu, Korea.

7. Oh SH, Kim DJ. 1998. Change of nucleotides, free amino acids in kwamaegi flesh by different drying for pacific saury, Cololabis saira. Korean J Food \& Nutr 11: 249-255.

8. Lee HJ, Oh SH, Choi KH. 2008. Studies on the general composition, rheometric and microbiological change of pacific saury, Coloabis saira kwamaegi on the storage temperatures and durations. J Korean Soc Food Sci Nutr 27: 165-175.

9. Lee HJ, Oh SH, Jeong JS, Choi KH. 2008. Studies on the rancidity of pacific saury, Cololabis saira kwamaegi on the storage temperatures and durations. Korean J Food \& Nutr 21: 477-484.

10. Kim YS, Oh SH, Kim SD. 2009. Antibacterial effects of chitosanon-ascorbate treated kwamaegi prepared on microorganism contamination. KSBB Journal 24: 156-162.

11. Yoon MS, Kim HJ, Park KH, Shin JH, Jung IK, Heu MS, Kim JS. 2009. Biogenic amine content and hygienic quality characterization of commercial kwamegi. Kor J Fish Aquat Sci 42: 403-410.

12. Kim MW, Kim YM. 2005. Isolation and identification of 
histamine degrading bacteria from kwamegi. Journal of Life Science 16: 120-125.

13. AOAC. 2005. Official methods of analysis. 18th ed. Association of Official Analytical Chemists, Washington, DC, USA. 927.05; 976.06; 954.02; 942.05.

14. Folch JM, Lees M, Sloane Stanley GH. 1957. A simple method for the isolation and purification of total lipids from animal tissues. $J$ Biol Chem 26: 497-509.

15. AOCS. 1989. Official and recommended practices of the American Oil Chemists' Society. 4th ed. AOCS Champaign, Chicago, IL, USA. Cd, 3a63; Cd, 853.

16. KFDA. 2002. Food Code. Korea Food and Drug Administration, Seoul, Korea. p 222-223.

17. Murray CK, Gibson DM. 1972. An investigation of the method of determining trimethylamine of fish muscle extracts by the formation of its picrate salt-part I. J Food Technol 7: 35-46.

18. Oh SH, Kim DJ. 1995. The change in content of constitutive lipid and fatty acid of pacific saury during natural freezing dry (kwa mae kee). Korean J Food \& Nutr 8:
239-252.

19. Kim DJ, Lee JW, Cho KH, Yook HS, Byun MY. 2000. Quality properties of gamma irradiated kwamegi (semidried Cololabis seira). Korean J Food Sci Technol 32: 1128-1134.

20. Gwak HJ, Eun JB. 2010. Chemical changes of low salt gulbi (salted and dried yellow corvena) during hot-air drying with different temperatures. Korean J Food Sci Technol 42: $147-154$

21. Lee EH, Oh KS, Ahn CB, Lee TH, Chung YH. 1987. Processing conditions and quality stability of seasoned sardine chopped-meat during frozen storage. $J$ Korean Fish Soc 20: 191-201.

22. Cho KH, Lee JW, Kim JH, Ryu GH, Yook HS, Byun MW. 2000. Improvement of the hygienic quality and shelf-life of kwamegi from Cololabis seira by gamma irradiation. Korean J Food Sci Technol 32: 1102-1106.

23. Walls I, Scatt VN. 1997. Use of predictive microbiology in microbial food safety risk assessment. Int $J$ Food Microbiol 36: 97-102.

(Received June 21, 2011; Accepted July 12, 2011) 